Original Research Paper

\title{
Mencegah dan Melawan Pandemi Covid-19 dengan Budidaya di Halaman Rumah di Desa Gunungsari Kabupaten Lombok Barat
}

\author{
Yamin Muhammad $^{1 *}$, Abdul Wahab Jufri ${ }^{1}$, Jamaluddin ${ }^{1}$, Khairuddin ${ }^{1}$ \\ ${ }^{\text {P} P r o g r a m ~ S t u d i ~ P e n d i d i k a n ~ B i o l o g i, ~ F a k u l t a s ~ K e g u r u a n ~ d a n ~ I l m u ~ P e n d i d i k a n ~ U n i v e r s i t a s ~ M a t a r a m, ~ M a t a r a m, ~}$ \\ Indonesia
}

DOI: https://doi.org/10.29303/jpmpi.v3i2.569

Sitasi:. Muhammad, Y., Jufri, A. W., Jamaluddin., \& Khairuddin. (2020). Mencegah dan Melawan Pandemi Covid-19 dengan Budidaya di Halaman Rumah di Desa Gunungsari Kabupaten Lombok Barat. Jurnal Pengabdian Magister Pendidikan IPA, 3(2)

\author{
Article history \\ Received: 25 Oktober \\ Revised: 15 Nopember \\ Accepted: 29 Desember \\ *Corresponding Author: Yamin \\ Muhammad, Program Studi \\ Pendidikan Biologi, Fakultas \\ Keguruan dan Ilmu Pendidikan \\ Universitas Mataram, Mataram, \\ Indonesia. \\ Email: \\ muhammadyamin.fkip@gamail.com
}

\begin{abstract}
Pandemi COVID-19 telah melanda Indonesia sejak Maret 2020. Untuk mengurangi penyebarannya, Pemerintah mengeluarkan sejumlah kebijakan diantaranya mengharuskan melakukan physical distancing, pembatasan sosial dan menghimbau masyarakat agar tetap di rumah. Hal ini tentu membuat masyarakat merasa bosan, stress dan sakit. Selain itu, juga dapat berdampak terhadap berbagai sektor, misalnya sektor pertanian dalam pemenuhan kebutuhan pangan masyarakat akan terganggu bahkan dapat menimbulkan krisis pangan karena terganggunya suplai. Kegiatan ini bertujuan untuk menunjang pemenuhan kebutuhan gizi dan ekonomi keluarga. Selain itu, memberikan keindahan, kesejukan, lingkungan yang nyaman, sehat dan menyenangkan juga sebagai sarana olah raga untuk meningkatkan kesegaran, kebugaran dan imun tubuh. Hal tersebut dapat mencegah bahkan melawan virus Covid 19 sehingga manusia Indonesia menjadi sehat dan cerdas. Pelaksanaan kegiatan dilakukan dengan penyuluhan, pelatihan dan pendampingan dengan metode Andragogi yaitu menekankan partisipasi aktif dari masyarakat peserta melalui kerja kelompok, demontrasi lapangan, dan diskusi. Kegiatan tersebut diikuti oleh 16 orang peserta dari desa lokasi dan melibatkan empat orang dosen dari program studi Pendidikan Biologi FKIP Universitas Mataram. Kegiatan budidaya yang dilakukan oleh khalayak sasaran yaitu bercocok tanam cabai (Capsicum annuиm), terong (Solanum melongena), bayam (Amaranthus sp) dan kemangi (Ocium ocium). Adapun model budidaya yang diterapkan pada khalayak sasaran adalah budidaya model vertikular, wadah pot dan bedengan serta pemeliharaan lele dalam ember.
\end{abstract}

Keywords: Budidaya; Covid-19; Pandemi; Pekarangan.

\section{Pendahuluan}

Pandemik COVID-19 telah melanda Indonesia sejak Maret 2020. Untuk mengurangi penyebarannya, Pemerintah mengeluarkan sejumlah kebijakan diantaranya mengharuskan melakukan physical distancing, pembatasan sosial dan menghimbau masyarakat agar tetap di rumah. Hal ini tentu membuat masyarakat merasa bosan, stress dan sakit. Selain itu, juga dapat berdampak terhadap berbagai sektor, misalnya sektor pertanian dalam pemenuhan kebutuhan pangan masyarakat 
akan terganggu bahkan dapat menimbulkan krisis pangan karena terganggunya suplai.

Sehubungan dengan hal tersebut di atas, kegiatan budidaya di halaman rumah merupakan solusi yang tepat. Lahan pekarangan dapat dikelola untuk menghasilkan berbagai macam produk untuk menunjang kebutuhan pangan keluarga seperti ikan, sayur mayur, bumbu dapur, rempah-rempah, tanaman obat dan buah serta tanaman hias.

Pekarangan rumah terutama di Dusun Kapek Atas Desa Gunungsari Kabupaten Lombok Barat belum dimanfaatkan secara optimal. Sumber daya tersebut bila dikelola dapat menghasilkan berbagai macam produk pertanian atau perikanan yang kini harganya sangat mahal seperti sayur mayur, bumbu dapur dan perikanan. Pengolahan lahan pekarangan untuk budidaya atau bercocok tanaman relatif mudah dan murah, karena tidak memerlukan kemampuan khusus dan modal yang besar. Jadi dapat dilakukan oleh hampir semua orang asal ada sedikit modal dan kemauan. Dengan demikian maka gizi keluarga akan terpenuhi, ekonomi rumah tangga dapat lebih terjamin, sekaligus menjadi sarana olahraga sehingga manusia Indonesia dapat tumbuh menjadi lebih sehat dan cerdas (Rusdi, $d k k$. 1998). Oleh karena itu sangat disesalkan bila lahan yang sebenarnya dapat memberikan banyak manfaat bagi kepentingan manusia tidak dimanfaatkandan dikelola secara optimal. Belum dikelolanya lahan pekarangan dapat disebabkan karena masyarakat belum tahu cara pemanfaatannya. Oleh karena itu, upaya pemberdayaan masyarakat yang terkait dengan penambahan pengetahuan, kesadaran dan keterampilan masyarakt untuk meningkatkan kesejahreraan masyarakat menjadi sangat penting. Program ini dimaksudkan untuk memberikan penyadaran dan keterampilan kepada masyarakat akan keuntungan bercocok tanam di lahan pekarangan.

Dari hasil pengamatan sepintas dan observasi di desa lokasi diketahui bahwa sesungguhnya masyarakat setempat mendambakan suatu model pendidikan alternatif yang memungkinkan mereka dapat diberdayakan dalam suatu usaha mandiri. Pendidikan (Pelatihan) masyarakat menjadi tumpuan harapan untuk peningkatan kualitas sumber daya manusia (SDM). Namun demikian, sistim pendidikan kita masih miss match terhadap tuntutan dunia kerja secara nasional maupun regional (Suyanto, 2001). Otoritas pendidikan selama ini telah melahirkan formula pendidikan yang tidak mampu melakukan pemberdayaan masyarakat, sehingga masyarakat kurang/tidak memiliki daya saing global; meskipun secara kuantitatif telah menunjukkan prestasinya (Suyanto, 2001). Kenyataan ini merata di seluruh propinsi, termasuk Propinsi Nusa Tenggara Barat.

Sejalan dengan uraian di atas, tujuan kegiatan ini selain untuk menunjang ekonomi dan pemenuhan kebutuhan gizi keluarga juga memberikan keindahan, kesejukan, lingkungan yang nyaman, sehat dan menyenangkan juga sebagai sarana olah raga untuk meningkatkan kesegaran, kebugaran dan imun tubuh untuk melawan virus Covid 19 sehingga manusia Indonesia menjadi sehat dan cerdas.

\section{Metode}

Pelaksanaan kegiatan pelatihan budidaya dilakukan dengan penyuluhan, pelatihan dan pendampingan dengan metode Andragogi. Metode ini menekankan partisipasi aktif dari masyarakat peserta melalui kerja kelompok, demontrasi lapangan, dan diskusi. Setiap peserta aktif mencari informasi dan terlibat dalam semua kegiatan pelatihan. Karena untuk mengetahui seluk-beluk kegiatan usaha harus diberikan atas dasar belajar mengajar. Kegiatan ini dilaksanakan dengan pemberian teori $15 \%$ dan praktek $85 \%$.

Kegiatan ini dilaksanakan selama 6 bulan melibatkan 4 orang dosen pendamping dari dosen FKIP Universitas Mataram dan 16 orang peserta dari desa lokasi. Kegiatan pengabdian ini ada dua tahapan yaitu tahap persiapan dan tahap pelaksanaan. Pada tahap pelaksanaan ada tiga kegiatan yang dilakukan yaitu 1) penyuluhan untuk penyampaian petunjuk tehnis bercocok tanam, 2) praktik bercocok tanam di lahan pekarangan dan 3) kegiatan pendampingan. Materi kegiatannya meliputi: melawan Pandemi Covid-19 dengan bercocok tanam di pekarangan rumah, bentuk dan jenis budidaya yang mudah dan cocok di pekarangan rumah serta manfaatnya.

\section{Hasil dan Pembahasan}

Selaras dengan tujuan kegiatan budidaya di lahan pekarangan untuk menunjang ekonomi dan pemenuhan gizi keluarga sekaligus, sebagai sarana olah raga untuk meningkatkan kesegaran, 
kebugaran dan imun tubuh. Selain itu, memberikan keindahan, kesejukan, lingkungan yang nyaman, sehat dan menyenangkan. Hal tersebut dapat mencegah bahkan melawan virus Covid 19 sehingga manusia Indonesia menjadi sehat dan cerdas. Sehubungan dengan hal tersebut, berikut disajikan kegiatan yang telah dilakukan.

\section{Penyiapan Media Tanah yang Baik}

Semua tanaman akan memiliki hasil produksi yang baik bila ditanam pada media yang baik. Media tanam yang baik adalah media yang mengandung banyak bahan organik, memiliki struktur yang gembur dan mengandung/dapat menyimpan cukup air. Untuk mendapatkan media seperti tersbut di atas dapat dilakukan dengan mencampurkan tanah dengan pupuk kandang dan sekam dengan perbandingan 2 bagian tanah, dengan masing-masing satu bagian pupuk kandang, kompos dan sekam. Perbandingan tersebut tidak mutlak yang penting bahan organik dan sekam yang ditambahkan cukup banyak sehingga media cukup subur dan rongga udaranya cukup. Berikut disajikan gambar penyediaan media tanam.

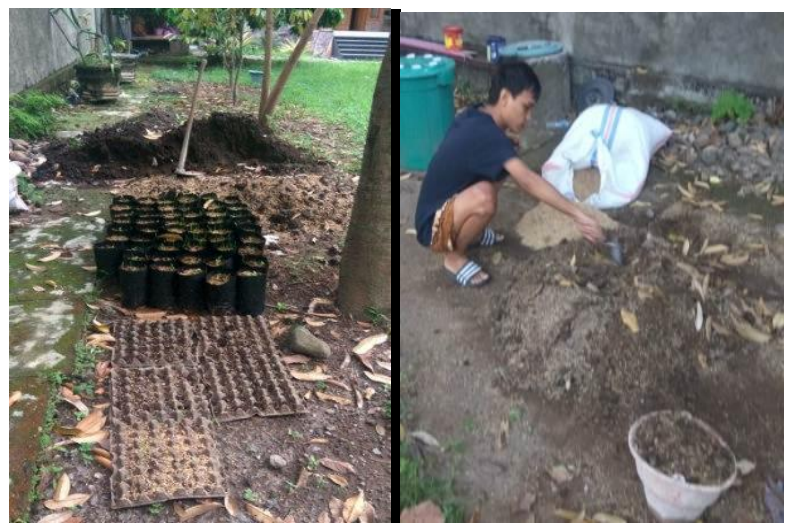

Gambar 1 dan Gambar 2 Penyediaan Media Tanam dalam pot

\section{Pilih Lahan yang Terkena Sinar Matahari}

Menanam sayuran secara organik sebaiknya dilakukan pada lahan yang mendapat sinar matahari penuh. Lahan sayuran tersebut harus tersinari setidaknya 6 - 10 jam sehari.

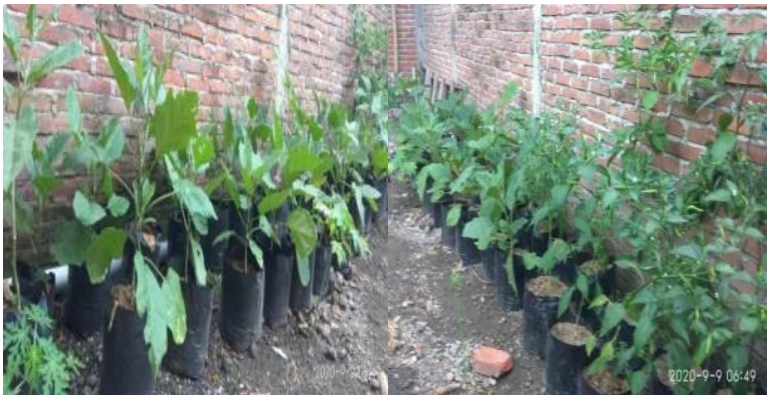

Gambar 3 dan 4 Lokasi penempatan agar mendapat cukup sinar matahari

\section{Memilih Jenis Budidaya yang Tepat dan Berkualitas}

Agar tanaman sayuran organik berhasil, harus mengetahui jenis sayuran dan varietas mana yang paling tepat untuk ditanam pada pekarangan. Bibit-bibit yang digunakan hendaknya yang sudah bersertifikat tanpa menggunakan pestisida atau bahan kimia lainnya. Pertimbangkan dari mulai jumlah sinar matahari yang diperlukan, cara merawat hingga proses pertumbuhannya. Proses pertumbuhan sayuran bergantung pada sifat alam, dan penyerbukan yang dapat membantu mereka. Ini merupakan salah satu faktor keberhasilan cara menanam sayuran organik di pekarangan rumah. Budidaya yang baik di lahan pekarangan misalnya tanaman Cabai (Capsicum annuum) dan terong (Solanum melongena). Cabai memiliki ukuran, warna, dan jenis berbeda seperti cabai merah, cabai keriting, cabai hijau, cabai rawit, hingga cabai setan. Cabai memiliki berbagai manfaat bagi kesehatan maupun kecantikan. Berikut sejumlah manfaat dari cabai yaitu: 1. Membunuh sel kanker, 2. Melancarkan pencernaan, 3. Meningkatkan kinerja otak, 4. Menghilangkan stress, 5. Mencegah obesitas dan membantu menurunkan berat badan, 6 . Membantu pembentukan sel darah merah, 7. Bersifat antiradang, 8. Mengobati panas dalam, terutama sariawan, 9. Mengatasi hidung tersumbat akibat flu atau pilek, 10. Memelihara kesehatan mata, 11. Mengurangi pusing, migrain, atau sakit kepala, 12. Mencegah bau napas, 13. Menjaga kesehatan jantung, 14. Meredakan nyeri sendi, 15. Meningkatkan sistem kekebalan tubuh, 16. Mengatasi Psoriasis atau gatal dan bercak pada kulit, 17. Mencegah infeksi jamur, 18. Bantu detoks racun. 19. Mencegah penuaan dini dan bikin awet muda 20. Menjaga kesehatan dan kekuatan rambut. Walaupun cabai memiliki banyak manfaat, sebaiknya mengonsumsinya sesuai dengan 
kemampuan perut dan tubuh, tidak terlalu banyak. Adapun tanaman. Terong merupakan salah satu jenis sayur yang rasanya lezat. Tekstur dagingnya unik mudah diolah menjadi berbagai macam makanan. Terong ada berbagai macam diantaranya terong hijau, terong ungu, terong putih, terong telunjuk, terong belanda, terong bulat, dan leunca. Dari jenis terong di atas, yang menjadi terong favorit dan sering dikonsumsi oleh masyarakat adalah terong ungu dan terong hijau atau terong lalap. Kedua jenis ini tidak hanya enak, manfaatnya pun banyak untuk kesehatan. Terong memiliki kandungan glikemik dan kalori yang rendah serta kandungan lemak yang sangat rendah. Selain itu, kadar airnya sangat tinggi sehingga kaya akan antioksidan, vitamin, dan juga mineral. Berbagai macam vitamin dan mineral yang terkandung dalam terong antara lain vitamin $\mathrm{A}$, vitamin $\mathrm{E}$, vitamin B1, vitamin B3, vitamin B2, vitamin B6, vitamin B9, vitamin B12, vitamin $\mathrm{K}$, kalsium, zat besi, kalium, sodium, fosfor, mangan, dan zinc. Kulit terong mengandung pigmen antosianin yang merupakan jenis antioksidan. Oelh kaerna itu, terong menjadi bahan makanan yang sering dipakai, menjadi berbagai hidangan makanan seperti terong lalap. Berikut disajikan sejumlah manfaat terong terutama terong hijau (Solanum melongena) yaitu: 1) mengendalikan kadar gula darah, karena menandung polifenol yaitu antioksidan yang dapat membantu mengurangi penyerapan glukosa dan jenis gula lainnya. Selain itu, polifenol ini juga berfungsi meningkatkan sekresi insulin yang menyebabkan kadar gula darah dapat terkendali dengan baik; 2) membantu mengendalikan kolesterol dalam tubuh. Seperti yang telah dijelaskan sebelumnya bahwa manfaat terong lalap dapat membantu mengendalikan kadar gula darah berkat adanya polifenol, sehingga bisa mengendalikan kolesterol dalam tubuh. Kemampuan terong dalam mengendalikan kadar gula ternyata juga memiliki efek ganda yaitu untuk menjaga kadar kolesterol dalam tubuh. 3) menjaga kesehatan jantung, karena mengandung antioksidan yang dapat m,ngonrol tingkat kolesterol LDI dan trigliserida dalam darah; 4) Mencegah kanker terutama terung ungu karena mengandung solasodine rhamnosyl glycoside yang dapat memicu kematian sel kanker sehingga dapat mencegah tumbuhnya sel kanker baru. Solasodine rhamnosyl glycoside juga disebut-sebut bisa digunakan untuk melawan kanker kulit bila digunakan secara optimal; 5) Berguna untuk otak, karena mengandung antosianin dan nasunin yang dapat menangkal radikal bebas. Kedua zat ini dapat melindung lipid yang terdapat pada membran sel otak. Selain itu, antosianin juga berfungsi untuk melancarkan peredaran darah ke otak sehingga dapat mengoptimalkan fungsi otak; 6) Membantu diet, karena memiliki kandungan serat yang tinggi dan juga rendah kalori; 7) Baik untuk kesehatan kulit, kandungan antioksidannya dapat membantu unuk menutrisi kulit sekaligus menjaga kesehatan kulit agar kulit tidak kering, mencerahkan warna kulit; 8) Mencegah osteoporosis, 9) Mengendalikan asam lambung, 10) Menurunkan resiko kebutaan, karena menandung antioksidan Lutein yang dipercaya dipercaya baik untuk menjaga kesehatan mata, selain itu juga dapat mencegah penyakit yang terjaid saat usia tua yaitu degenerasi maskular, yang dapat menyebabkan kehilangan fungsi penglihatan, 11) Mmencegah anemia, kaena mengandung zat besi yang cukup untuk menjaga fungsi sel darah merah dalam membantu tubuh beraktifitas.

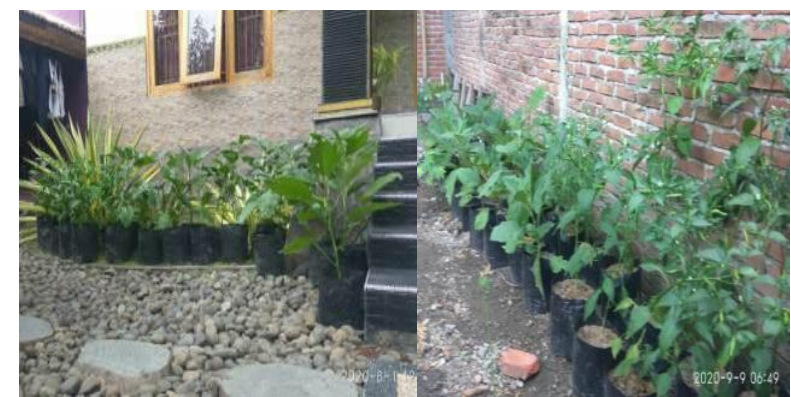

Gambar 5 dan 6 Jenis Tanaman yang cocok di lahan Pekarangan

Budidaya di lahan pekarangan selain yang cocok diantaranya adalah beternak ikan lele dumbo (Clarias gariepinus). Budidaya lele tak asing lagi di masyarakat krena menguntungkan dan dapat majadi mata pencaharian tetap. Hal penting yang perlu diketahui dalam budidaya lele adalah 1) Memahami cara budidayanya, 2) Memahami potensi pasar, 3) Memahami cara budidaya yang cocok untuk Anda. Ada beberapa cara yang bisa dilakukan untuk membudidayakan ikan lele yaitu dengan menggunakan kolam tanah, menggunakan kolam terpal dan menggunakan kolam beton atau kolam semen. Untuk dipekarangan yang sempit dapat dilakukan dengan pemeliharaan dalam ember seperti berikut. 


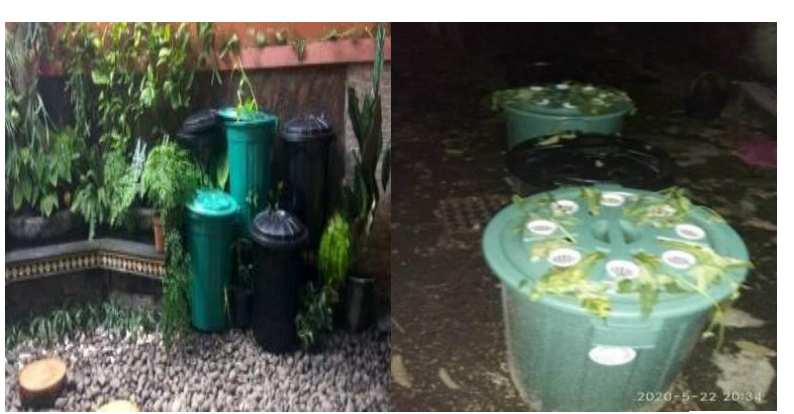

Gambar 7 Budidaya lele dumbo (Clarias gariepinus).

\section{Pembibitan}

Wadah pembibitan dapat berupa tray khusus pembibitan atau dapat juga wadah lain seperti baki plastik, pot plastik, kotak dari kayu, kantong plastik, polybag, dll. Media pembibitan yang digunakan sama seperti di atas namun perlu lebih halus dengan menghindari bongkahan atau kerikil dengan cara disaring menggunakan saringan kawat berdiameter lubang 2-5 mm. Pembibitan umumnya dilakukan untuk benih-benih yang berukuran kecil dan berharga relatif mahal sepeti terong, sawi, selada, cabai, tomat, dll. Sementara itu, benih berukuran besar umumnya ditanam langsung dalam wadah penanaman. Berikut disajikan gambar wadah media pembibitan.

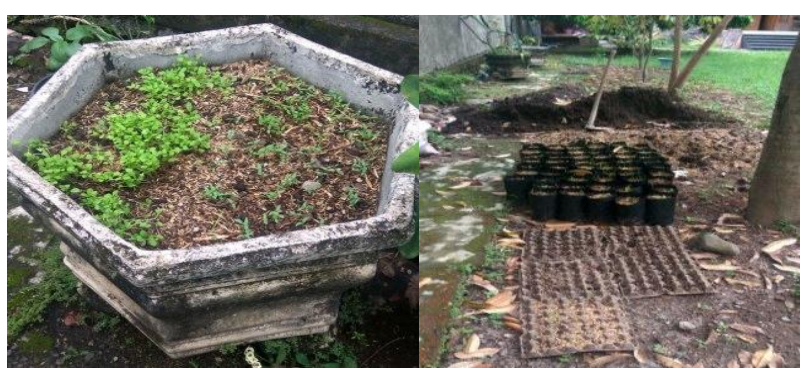

Gambar tanaman sawi, terong cabai dan tomat.

\section{Penanaman}

Penanaman di dalam rak vertikultur atau pot dilakukan setelah bibit memiliki daun sempurna 3-5 helai. Langkah-langkah penanaman adalah : 1) Pilih bibit yang sehat, tidak cacar, dan seragam. 2) Buat lubang tanam seukuran wadah bibir. Pada sistem vertikultur rak berjenjang, jarak tanam berkisar 10$15 \mathrm{~cm}$. Pada sistem pot, jumlah tanaman yang ditanam sebanyak 1 tanaman per pot pada pot berukuran $3-10 \mathrm{~kg}$, sedangkan untuk pot berukuran lebih besar jumlah tanaman berkisar 2-3 tanaman, khususnya untuk sayuran buah merambat seperti pare timun, oyong, dan tanaman sejenis lainnya. 3)
Keluarkan bibit secara hati-hati dengan cara menggunting wadah atau membalikkan wadah sedemikian rupa sehingga media dan perakaran bibit tidak terganggu. 4) Masukkan bibit ke dalam lubang tanam, selanjutnya tutup lubang tanam menggunakan media tanam yang sebelumnya dikeluarkan pada saat membuat lubang tanam. 5) Lakukan penyiraman hingga media tanam menjadi basah secara merata.

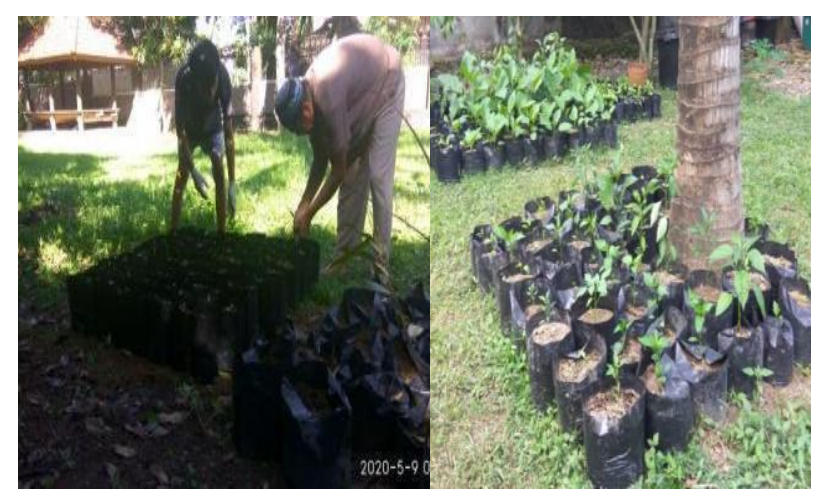

Gambar Penanaman bibit cabai, terong dan tomat

\section{Pemupukan}

Pupuk dapat berupa pupuk organik cair yang telah tersedia di toko-toko sarana pertanian atau dengan cara membuat sendiri. Intensitas pemberian pupuk organik biasanya dilakukan 3-7 hari sekali dengan cara melarutkan 10-100 ml pupuk dalam 1 liter air dan disiramkan secara merata pada media tanam. Pada sayuran buah, disebabkan masa pertumbuhan yang lebih panjang, maka selain pemberian pupuk organik cair juga dapat dilakukan pemberian pupuk susulan berupa pupuk kandang atau pupuk kompos setiap 30 hari sekali sebanyak 50-100 g atau 2-3 genggam pupuk per tanaman. Pembuatan pupuk organik cair (POC) dapat dilakukan dengan menggunakan bahan dan alat sebagai berikut : (1) ember atau gentong plastik berukuran $50 \mathrm{lt}$, (2) kantong kain, (3) pupuk kandang atau kompos atau kascing $5 \mathrm{~kg}$, (4) molase 2 lt, (5) EM $100 \mathrm{ml}$, dan (6) air $40 \mathrm{lt}$.

\section{Penyiraman}

Intensitas penyiraman sangat tergantung pada volume media tanam, populasi tanaman, dan fase pertumbuhan tanaman. Semakin kecil volume media tanam atau semakin besar ukuran tanaman serta populasinya, maka intensitas penyiraman harus lebih sering. Namun demikian, penyiraman umumnya dilakukan 1 sampai 2 kali sehari. Perlakuan penyiraman harus diperhatikan pada saat 
pembungaan dan pembesaran buah. Keterlambatan penyiraman akan menyebabkan bunga atau bakal buah menjadi rontok. Penyiraman harus dilakukan secara hati-hati dengan menggunakan alat siram berupa slang plastik.

\section{Pengendalian Hama dan Penyakit}

Pengendalian hama dapat dilakukan secara fisik dengan cara membunuh atau membuang hama yang terdapat pada tanaman dan media tanam atau secara kimiawi dengan insektisida nabati. Insektisida nabati telah banyak dijual di kios-kios pertanian. Apabila tidak tersedia agensia hayati, pengendalian penyakit dapat dilakukan dengan cara memusnahkan tanaman terserang sehingga tidak menulari tanaman lainnya. Untuk penyakit virus yang penyebarannya diperantarai serangga, misalnya kutu pucuk dan kutu daun, pengendalian dapat dilakukan dengan cara menghalangi serangan serangga vektor melalui aplikasi pestisida nabati. Selain itu, untuk menghindari tanaman dari hama dan penyakit lainnya serta menipisnya tanah dari nutrisi dapat dilakukan dengan merotasi tanaman setahun sekali.

\section{Kesimpulan}

Dari uraian dalam kegiatan dan pembahasan mengenai budidaya di lahan pekarangan rumah memiliki banyak manfaat. Manfaatnya selain memberikan keindahan, kesejukan, lingkungan yang nyaman, sehat dan menyenangkan, juga untuk menunjang pemenuhan kebutuhan gizi dan ekonomi keluarga sebagai sarana olah raga untuk meningkatkan kesegaran, kebugaran dan imun tubuh. Hal tersebut dapat mencegah bahkan melawan virus Covid 19 sehingga manusia Indonesia menjadi sehat dan cerdas.

\section{Daftar Pustaka}

Anonim, 2019. Buku Panduan praktis bertanam sayuran.Penebar Swadaya, 2019.

Badan Pusat Statistik Kabupaten Lombok Barat, 2018. Kabupaten Lombok Barat Dalam Angka. Lombok Barat, 2018.

Cayana, S.ST. Penyuluh Pertanian Pertama, Wilbi Desa Patikarta Kecamatan Bontosikuyu

https://www.pertanianku.com/3-hal-yang-perluanda-tahu-sebelum-budidaya-lele-dumbo/ https://finance.detik.com/berita-ekonomi-bisnis/d5005157/kementan-dorong-pemanfaatanlahan-pekarangan-untuk-kebutuhanpangan?_ga=2.145188540.920076541.1591 517764-1557988405.1588144999.

https://www.cnnindonesia.com/gayahidup/20200504131813-284-499816/carasederhana-persiapan-berkebun-di-rumahbagi-pemula.

http://hsarifin.staff.ipb.ac.id/2020/04/14/berkebundi-pekarangan-selama-bekerja-dari-rumah/;

https://www.pertanianku.com/3-hal-yang-perluanda-tahu-sebelum-budidaya-lele-dumbo/

https://katadata.co.id/infografik/2020/05/07/krisispangan-akibat-covid-19

Novie Rahmayanti, Bola,com. Desember 2019. http://blog.sayurbox.com/9-manfaat-terong-lalap/

R. H. Peru, Trias Qurnia Dewi dan Hendro Suwarjono. 2019. Buku Panduan Praktis Bertanam Sayuran di Pekarangan. Penebar Swadaya. 